„Studia Wyborcze”, tom 32, 2021

DOI: https://doi.org/10.26485/SW/2021/32/8

\title{
GRZEGORZ KRYSZEŃ, REFERENDUM JAKO INSTYTUCJA DEMOKRACJI BEZPOŚREDNIEJ, Wydawnictwo Temida 2, Białystok 2020, ss. 184
}

W polskim prawniczym i politologicznym piśmiennictwie naukowym można znaleźć wiele monografii oraz prac przyczynkarskich poświęconych instytucji referendum. Jest to zrozumiałe, gdyż to problematyka rozległa, wieloaspektowa, w której ściera się szereg różnych poglądów, a jednocześnie w praktyce referendum jest marginalizowane przez polityków, co prowadzi wręcz do podważenia jego znaczenia ustrojowego. Ostatnio literatura ta wzbogaciła się o bardzo cenną pracę Grzegorza Kryszenia Referendum jako instytucja demokracji bezpośredniej (Białystok 2020, ss. 184), do zapoznania się z którą chciałbym gorąco zachęcić wszystkich interesujących się nie tylko instytucją referendum, ale również szerzej - demokracją bezpośrednią i jej formami. Jest to bowiem bardzo ciekawa wypowiedź cenionego konstytucjonalisty, będącego wielkim zwolennikiem korzystania z referendum w ogólnokrajowych i lokalnych procesach decyzyjnych, który omawia je w sposób całościowy, a zarazem formułuje wiele bardzo cennych uwag pod adresem polskich rozwiązań prawnych w tym zakresie.

Pisząc monografię autor postawił sobie trzy główne zadania, na które wskazał wprost we wstępie. Po pierwsze, było to dokonanie charakterystyki instytucji referendum jako procedury demokracji bezpośredniej. Po drugie, wskazanie rozwiązań prawnych i postulowanych normatywnych standardów, które mogłyby najpełniej stymulować wytworzenie się warunków do pełnienie przez referenda oczekiwanej od nich roli urzeczywistniania zwierzchniej władzy konstytucyjnego podmiotu suwerenności - narodu. Po trzecie, konfrontacja ze wskazanymi rozwiązaniami modelowymi aktualnych polskich regulacji prawnych referendum ogólnokrajowego i referendów lokalnych (s. 9). Zadania te zostały w całej pełni zrealizowane. 
Wielką zaletą pracy jest jej bardzo prosta konstrukcja, która z jednej strony ułatwiła autorowi prowadzenia rozważań, zaś drugiej strony pomaga czytelnikowi w zrozumieniu prowadzonych w pracy wywodów. Dwa pierwsze rozdziały mają charakter czysto teoretyczny i poświęcone są odpowiednio demokracji bezpośredniej i jej znaczeniu w realizacji idei zwierzchnictwa narodu (rozdział I) oraz instytucji referendum i jej istocie (rozdział II). Kolejny rozdział przedstawia demokratyczne standardy prawa referendalnego, które wskazywane są w Kodeksie dobrej praktyki referendalnej. Wreszcie ostatni rozdział IV poświęcony jest polskiemu prawu referendalnemu, zarówno ogólnokrajowemu, jak i lokalnemu. Wprawdzie Grzegorz Kryszeń wskazuje $\mathrm{w}$ jego tytule, że omawia wyłącznie wybrane zagadnienia, to w rzeczywistości jest to właściwie całościowe bardzo umiejętne przedstawienie obu instytucji, a w każdym razie najważniejszych związanych z nimi problemów. Pracę otwiera wspomniany już wstęp, w którym przedstawione są nie tylko zadania, które przyświecały autorowi przy jej pisaniu, ale i sygnalizowane jest jego zainteresowanie praktyką, co pozwoli na konfrontację założeń teoretycznych i krytycznej analizy regulacji prawnych analizowanej instytucji z jej wykorzystaniem w życiu społeczno-politycznym. Należy jedynie żałować, że monografia nie jest zwieńczona żadnym zakończeniem podsumowującym wyniki bardzo interesujących rozważań. W ten sposób monografia pozbawiona jest końcowej rekapitulacji najważniejszych tez i zgłaszanych wielu cennych postulatów. Potrzeba takiego zakończenia wydaje tym większa, że nie ma również takich zwieńczeń w poszczególnych rozdziałach.

Grzegorz Kryszeń pokazuje w rozdziale I różne znaczenia istotnych dla rozważań pojęć, jak i posługiwanie się nimi w różnych aspektach. Odnosi się to przede wszystkim do pojmowania demokracji partycypacyjnej oraz demokracji bezpośredniej (s. 14). Podkreśla przy tym, że niektóre z nich mają już dzisiaj znaczenie jedynie historyczne. Przywołuje również, chyba częściowo zapomniane obecnie, pojęcia republiki bezpośredniej, republiki pośredniej i republiki pośredniej z bezpośrednim udziałem ludności w rządach, o których pisał Zygmunt Cybichowski (s. 16). Generalnie akcentuje, że brakuje ogólnie akceptowanych definicji tych pojęć, co ma też konsekwencje w postaci braku np. zgody co do form instytucjonalnych demokracji bezpośredniej (s. 26); powoduje to, że w najwęższym ujęciu ogranicza się to do zaliczenia do nich zgromadzeń i referendum, zaś w najszerszym, które występowało w czasach socjalistycznych, obejmowało również ławników ludowych, związki zawodowe czy samorząd robotniczy (s. 33). Grzegorz Kryszeń opowiada się przy tym za najbardziej radykalnym pojmowaniem demokracji bezpośredniej obejmującej ogół form instytucjonalnych. 
Autor, będąc gorącym zwolennikiem demokracji bezpośredniej, przywołuje jednak również występujące $\mathrm{w}$ literaturze przedmiotu argumenty przemawiające przeciwko niej oraz podejmuje z niektórymi z nich trafną polemikę (s. 17 i n). Za demokracją bezpośrednią przemawia jednak to, że najpełniej wyraża ona ideę suwerenności narodu. Odrzuca również koncepcję demokracji semibezpośredniej i uważa, że obok demokracji bezpośredniej i pośredniej jest jeszcze trzecia płaszczyzna urzeczywistniania idei suwerenności narodu, która wyraża się w inspiracji i formułowaniu opinii, a jej formami są referendum konsultacyjne, inicjatywa ludowa i (co jest chyba dyskusyjne) veto ludowe (s. 27/28). Bardzo mocno akcentuje również, że demokracją bezpośrednią nie są wybory i możliwość odwołania organu czy poszczególnych członków wybieranych ciał kolegialnych (s. 30). W związku z tą drugą możliwością na uwagę zasługuje słusznie podnoszony zarzut, że nazywanie jej „referendum” jest błędne, gdyż w tym przypadku nie mamy do czynienia z decyzją rzeczową lecz personalną (s. 31-32).

Istota poglądów Grzegorza Kryszenia sprowadza się do stwierdzenia, iż „ideę bezpośrednich rządów narodu w rzeczywistości odzwierciedla i symbolizuje w państwach współczesnych tylko instytucja referendum” (s. 32), gdyż inne jej instytucje w praktyce są wykorzystywane sporadycznie lub wcale. Dlatego dopuszcza, aby zamiast używania określenia ,demokracja bezpośrednia” posługiwać się terminem „demokracja referendalna” (s. 32).

Autor w bardzo umiejętny sposób prowadzi narrację w celu pokazania, że demokracja przedstawicielska $\mathrm{w}$ istocie nie sprawia, że suweren, którym jest naród (lud), rzeczywiście sprawuje władzę permanentnie i niepodzielnie. Trafnie pokazuje, że suweren jest od tej władzy odsunięty i realizuje ją w zasadzie wyłącznie w wyborach powszechnych. I dlatego tak ważne jest poszukiwanie instrumentów demokracji bezpośredniej, które pozwolą na włączenie się suwerena w procesy decyzyjne i w zarządzanie sprawami państwowymi. Istnieje też potrzeba rozwijania pozaprzedstawicielskich form partycypacji społecznej.

W rozdziale I na uwagę zasługują, moim zdaniem, jeszcze trzy tezy. Pierwsza, będąca konsekwencją śmiałej polemiki ze stanowiskiem Trybunału Konstytucyjnego, jest innym odczytaniem treści art. 4 ust. 2 Konstytucji RP. Zdaniem Grzegorza Kryszenia demokracji bezpośredniej na gruncie tego przepisu nie można odczytywać jako uzupełnienia dla demokracji przedstawicielskiej (s. 38). Druga to, pomimo opowiadania się za demokracją bezpośrednią, podkreślenie, że nie chroni ona we właściwy sposób mniejszości (s. 42). I trzecia, to chyba zrozumiałe twierdzenie, że przyszłość należy do demokracji elektronicznej; $w$ tym przypadku stawia jednak również ciekawe pytania, które należy traktować bardziej jako postawienie problemu, nie zaś próbę odpowiedzi na nie. 
Rozdział II recenzowanej monografii to bardzo udane skondensowane przedstawienie instytucji referendum i jego istoty. Omawiając poszczególne kwestie Grzegorz Kryszeń, w pełni trafnie, nawiązuje do analogicznych rozważań na temat wyborów i nawet konfrontuje je ze sobą. Jest to szczególnie widoczne w przypadku przedstawiania funkcji, które pełnią referenda (s. 49 i n.), ale i zasad prawa referendalnego (s. 63 i n.), przy czym w pełni zasadnie zwraca uwagę, iż w doktrynie te drugie są niesłusznie pomijane. W przypadku przedstawiania różnych klasyfikacji instytucji referendum szczególnie dużo miejsca poświęcone jest kryterium jego przedmiotu i w jego ramach również wyróżnione są różne podziały (s. $54 \mathrm{i} \mathrm{n}$.). Jest to cenne $\mathrm{z}$ uwagi na to, że w polskim piśmiennictwie zagadnienie to nie jest tak mocno rozbudowywane.

Zachęcając do lektury tej pracy, chciałbym zwrócić uwagę na akcentowanie przez autora niebezpieczeństwa, które niosą ze sobą referenda, za którymi kryje się kwestia udzielenia społecznego poparcia dla przywódców politycznych. O ile w państwach demokratycznych są one do zaakceptowania, to w niedemokratycznych państwach autorytarnych i totalitarnych służą jedynie do nadania tym reżimom demokratycznej fasady i dlatego nie mogą być traktowane w taki sam sposób jak te pierwsze (s. 50-51).

W rozdziale tym jest też dużo i w ciekawy sposób powiedziane o polskiej i zagranicznej praktyce referendalnej. Jednocześnie Grzegorz Kryszeń wyraźnie podkreśla jednak, że książka jest poświęcona doktrynalnym i prawnym aspektom procedury referendalnej, a nie uwarunkowaniom politycznym, socjologicznym lub historycznym referendów (s. 70 i n.). Referenda, akcentuje, powinny być przy tym w przyszłości wykorzystywane częściej, ale trzeba je wzmacniać i udoskonalać (s. 68).

Podobnie jak w przypadku wyborów, również referenda powinny być przeprowadzane według pewnych (międzynarodowych) standardów. Poświęcony jest im rozdział III recenzowanej monografii. Autor szczegółowo omawia Kodeks dobrej praktyki referendalnej, który został przyjęty przez Komisję Wenecką w dniach 13-14 października 2006 roku po ich wypracowaniu przez Radę na rzecz Demokratycznych Wyborów oraz jego „aktualizację” dokonaną w 2020 roku. Dokument ten, co może nawet dziwić, nie był, jak dotąd, przedmiotem szerszej analizy w polskim piśmiennictwie naukowym, stąd szczególna wartość poświęconych mu rozważań. Kodeks obejmuje swoimi postanowieniami wszystkie istotne zagadnienia z zakresu prawnych regulacji instytucji referendum. Trzeba jednak pamiętać, że jest on tzw. miękkim prawem, stąd nie obowiązuje bezwzględnie, a jedynie ma być pomocny państwom członkowskim Rady Europy, a zwłaszcza Europy Środkowej i Wschodniej, w konstruowaniu instytucji referendów ogólnokrajowych i lokalnych oraz ich przeprowadzaniu. 
Grzegorz Kryszeń, analizując postanowienia kodeksu zasadnie nie omawia szczegółowo wszystkich zawartych $\mathrm{w}$ nim zaleceń. Wynika to z faktu, że większość z nich jest taka sama, czy bardzo zbliżona, do zaleceń znajdujących się w Kodeksie dobrych praktyk wyborczych. Takie zasady są jedynie sygnalizowane. Dlatego uwagę skupia na trzeciej części kodeksu, w której zawarte są „,normy specyficzne” dla organizacji i przeprowadzania referendów (s. 88 i n.). Bardzo trafne jest w tym przypadku podkreślanie, iż wymóg frekwencji nie jest w przypadku referendów właściwy, gdyż osoby niegłosujące czyni osobami głosującymi przeciw (s. 89). Omawiając zarówno zasady, jak i niedawną „,aktualizację”, zwraca uwagę na konieczność niezależności i reprezentatywności komisji przeprowadzających referenda (s. 86), ale i niezależność organu nadzorującego przebieg referendum i stwierdzającego jego ważność (s. 94).

Za szczególnie ważne w rozważaniach Grzegorza Kryszenia uważam wskazanie na podniesioną $\mathrm{w}$ kodeksie konieczność istnienia niezależnego organu weryfikującego pytania proponowane do postawienia $\mathrm{W}$ referendum (s. 94). W szczególności odnosi się to do kwestii badania ich konstytucyjności czy szerzej - zgodności z prawem, zwłaszcza jeżeli są ustawowe wyłączenia niektórych materii spod referendum. Nie ulega wątpliwości, że nie powinni tego czynić politycy, czy formalnie organ, w którym oni zasiadają. Za dyskusyjny uważam jednak pogląd, że taki organ nadzoru powinien mieć prawo korygowania proponowanych pytań. Jest to kwestia zasługująca na szerszą dyskusję, powstaje bowiem niebezpieczeństwo zniekształcenia czy wręcz wypaczenia celu przyświecającego podmiotowi występującemu z wnioskiem o zarządzenie referendum, czy chcącemu je zarządzić.

O trafnym odniesieniu się autora monografii do Kodeksu dobrych praktyk referendalnych dowodzi konkluzja, iż nie jest to dokument wolny od wad i wiele jego postanowień nie jest sformułowanych z należytą precyzją (s. 92).

W ostatnim IV rozdziale monografii Grzegorz Kryszeń konfrontuje polskie regulacje instytucji referendum z wcześniejszymi czynionymi w pracy rozważaniami. Większy nacisk kładzie przy tym na rozwiązania odnoszące się do referendum ogólnokrajowego, chyba niesłusznie uważając, że referenda lokalne są lepiej unormowane. Przedstawienie obu unormowań jest całościowe i syntetyczne $\mathrm{z}$ wydobyciem wszystkich istotnych dla nich zagadnień.

Niewątpliwą zaletą tej części książki jest formułowanie wielu postulatów pod adresem tak regulacji konstytucyjnej, jak i ustawowej. O ile niektóre są słuszne, jak np. wprowadzenie cenzusu czasu zamieszkiwania w danej jednostce samorządu terytorialnego jako warunku udziału w referendum lokalnym, czy stworzenia jednego wspólnego kodeksu wyborczego i referendalnego (s. 109), to inne mogą być dyskusyjne. Za taki uważam, przykładowo, propozycję wprowadzenia w Konstytucji RP wyodrębnionego rozdziału poświęconego referendum. Na świecie jest niewiele państw, które w ustawach zasadniczych 
mają wyodrębnione rozdziały poświęcone wyborom (jak miało to miejsce np. w Konstytucji PRL z 1952 r.) i nie jest to raczej przypadkowe. W Polsce powraca się do idei takiego rozwiązania i nie jestem mu przeciwny, wymaga to jednak dyskusji i wnikliwego rozważenia. Powstaje również pytanie, czy materia wyborcza i referendalna powinna być w jednym, czy w dwóch rozdziałach konstytucji? No i otwarta pozostaje kwestia zakresu tej regulacji.

Spośród wielu podnoszonych w monografii kwestii chciałbym wskazać na rozważania o możliwości przeprowadzenia w Polsce referendum w sprawach ustrojowych z wykorzystaniem art. 125 Konstytucji (s. 114). Jak wiadomo, jest to problem zarówno teoretyczny, jak i praktyczny i trudno uznać, aby ta druga rozstrzygnęła to w 2015 roku. Bardzo interesujące są też uwagi Grzegorza Kryszenia odnośnie do problemu badania konstytucyjności zarządzenia referendum i jego pytań oraz postulat powierzenia czynienia tego przez Trybunał Konstytucyjny (s. 122).

Niestety trzeba też ze smutkiem przyznać rację autorowi, że rola suwerena - narodu - jest w Polsce ograniczana tak przez przepisy prawa, jak i praktykę (s. 116), a referendum ogólnokrajowe ma postać referendum kontrolowanego, gdyż o jego przeprowadzeniu decydują rządzący. Dlatego trafny jest postulat obligatoryjności referendum $\mathrm{w}$ przypadku wystąpienia $\mathrm{z}$ wnioskiem przez odpowiednio liczną grupę obywateli, jak ma to miejsce w wielu krajach europejskich, chociaż sporna jest oczywiście kwestia, ile powinna ona liczyć osób. W pełni zasadne są też zawarte w książce krytyczne uwagi na temat powierzenia w 2018 roku kompetencji Sądu Najwyższego weryfikowania wyników referendów (i wyborów) Izbie Kontroli Nadzwyczajnej i Spraw Publicznych, której status budzi, jak wiemy, poważne zastrzeżenia (s. 150).

Podsumowując recenzję, chciałbym jednoznacznie stwierdzić, że monografia Grzegorza Kryszenia Referendum jako instytucja demokracji bezpośredniej jest pozycją zasługującą na uwagę oraz że jest to lektura obowiązkowa dla wszystkich prawników i politologów zajmujących się problematyką referendalną. 